\title{
Potency of Allium sativum and Allium cepa Oils against Schistosoma mansoni Infection in Mice
}

\author{
Nadia S. Metwally \\ Medicinal Chemistry Department, National Research Center, \\ Dokki, Cairo, Egypt.
}

\begin{abstract}
:
Introduction: It has been reported that garlic (Allium sativum) and onion (Allium cepa) are used all over the world in different diseases, such as infections, injuries, gastrointestinal dysfunctions and cardiovascular diseases. Therefore, our aim in this work was to study the ability of garlic and onion oils to offset the infectivity as well as the metabolic disturbances induced by Schistosoma mansoni parasitism.
\end{abstract}

Methods: The two current drugs were given in a dosage of $5 \mathrm{ml} / \mathrm{kg}$ body weight/ day. Three aspects of drug action were investigated, the effect on $S$. mansoni infection, the effect on liver functions, and on liver metabolism. The parasitological investigation included worm burden and ova count.

Results: Serum biochemical analysis of infected mice revealed a significant increase in the levels of aspartate aminotransferase (AST), alanine aminotransferase (ALT) , $\gamma-$ glutamyltransferase (GGT), alkaline phosphatase ( ALP), acid phosphatase (AP), while a decrease in glucose, total lipids total cholesterol, high - and low- density lipoproteins cholesterol (HDL and LDL), triglycerides, total proteins and albumin was observed. Liver tissue analysis of infected animals showed a marked increase in L- hydroxyproline (HP) concentration and xanthine oxidase (XO) activity accompanied with a reduction in total adenosinetriphosphatase (ATPase) and phosphofructokinase (PFK) enzymatic activities. Treatment with either garlic or onion oils greatly normalized liver function enzymes and variably improved the other parameters with a noticeable reduction in worm burden and ova count.

Conclusions: It could be concluded that garlic or onion may play a role against the metabolic disturbances caused by $S$. mansoni infection, owing to an effect which may be induced by improving the immunological host system and their antioxidant activities.

Key words: A. sativum - A. cepa - S. mansoni - Worm burden - Ova count - Serum analysis - liver analysis.

\section{Introduction}

Schistosoma mansoni, a helminthic parasite, that causes human bilharziasis, settles in the mesenteric veins of the gut, its eggs migrate to the liver where they induce a delayed hypersensitivity response. In schistosomiasis, morbidity and mortality are due to a unique form of liver fibrosis followed by portal hypertension as the main complication. The egg cuticle, composed of cross - linked proteins, encloses a larva that releases enzymes and antigens through multiple pores. The host reaction presumably involves reactive oxygen species (ROS) (Caulfield et al., 1985). The production of ROS initiates a fibrogenesis cascade in the liver (Casini et al., 1997). In the chronic phase of infection, liver fibrosis and its confluences can eventually lead to death.

Current control of the disease by chemotherapeutic agents is impractical because of the common occurrence of re infection after treatment due to relative resistance of the larval stages of S.mansoni to schistosomicide drugs (Silva et al., 2003). Praziquantel, the currently used drug for chemotherapeutic control, was reported to induce hemorrhage in the lung tissue of the host (Flisser \&Mclaren, 1989) as well as abdominal pain and diarrhea (Kabatereine et al., 2003). So for combating 
schistosomiasis there is an urgent need to develop new drug alternative to praziquantel. The new trends nowadays are the use of natural plant extracts as new, safe and effective drugs.

Garlic (A. sativum Linn.) which is widely used as a food or condiment has been known since ancient times as a flavoring agent and for its medicinal properties. The major volatile compounds of garlic are sulfur- containing compounds ( $\mathrm{Yu}$ et al., 1989). In addition, it has been reported that garlic oils inhibit tumor promotion (Karasaki et al ., 2001), it has different applications as antimicrobial (Yoshida et al., 1998) antithrombotic , antiarthritic , hypolipidemic, and hypoglycemic agent (Duraka et al., 2002 ; Kumar et al., 2003) . Moreover, Ghazanfari et al. (2002) and Hassan et al. (2003) demonstrated that garlic enhanced $\mathrm{T}$ lymphocyte proliferation, delayed type hypersensitivity and natural killer (NK) cell activity. Recently, Ghazanfari et al. (2006) reported that garlic is used all over the world in different diseases, such as infections, cancers, injuries, gastrointestinal dysfunctions and cardiovascular diseases.

Onion (A. cepa Linn.) is a plant of particular medicinal importance; it is used as traditional remedy in the treatment of various disorders (Griffiths et al., 2002). Several authors have reported pharmaceutical effects of extracts of $A$. cepa including antitumor, antidiabetic, antioxidant, antimicrobial, antiallergic and molluscicidal activities (Belman , 1983 ; Kumari et al ., 1995 ; Helen et al ., 2000 ; Mantawy \&Mahmoud, 2002). Saleheen et al.(2004) reported that aqueous onion extract has an antileishmanial activity, suggesting that onion has an antiparasitic activity.

In view of these findings, the present study was undertaken to determine the possible antischistosomal effects of the expressed oils of A. sativum and A. cepa in $S$. mansoni infected mice. This was conducted through measuring some biochemical parameters in both serum and liver tissues. Serum parameters include, AST, ALT, GGT, ALP, AP, glucose, total lipids, total cholesterol, HDL, LDL, triglycerides, total proteins and albumin.
The effect on liver tissue was evaluated by measuring L- hydroxyproline concentration $\mathrm{XO}$, total ATPase and PFK enzymatic activities. Parasitological studies namely, worm burden and ova count will be taken into consideration.

\section{Material and Methods}

\section{Chemicals:}

All chemicals used in the present study were of analytical grade, products of Sigma (USA), Merck (Germany) BDH (England).

\section{Animals:}

Sixty female Swiss albino mice aging 6-8 weeks and weighing 18-20 $\mathrm{g}$ were obtained from the Animal House of the National Research Center. Mice were provided with balanced commercial pellet diet and water ad libitum during the study.

\section{Experimental design:}

Animals were divided into six groups, each group of 10 mice. Group 1: served as healthy control. Group 2: served as a healthy control given garlic oil. Group 3: served as a healthy control given onion oil. Group 4: infected with $S$. mansoni. Group 5: infected with $S$. mansoni and treated with garlic oil after $24 \mathrm{hr}$ post infection. Group 6: infected with $S$. mansoni and treated with onion oil after $24 \mathrm{hr}$ post infection. Garlic or onion oils were given in a dosage of $5 \mathrm{ml} / \mathrm{Kg}$ body weight orally for 8 weeks daily.

\section{Infection:}

Each mouse in the infected groups was exposed separately to 80 cercariae for $1 \mathrm{~h}$, using the partial immersion technique (Oliver \& Stirewalt, 1952). Cercarial suspensions were obtained from at least 15 Biomphalaria alexandrina snails infected with the local strain of $S$. mansoni prevailing in Egypt. All groups were examined 8 weeks after infection.

\section{Worm counting:}

Worms were recovered from the hepatic portal system and liver by a perfusion technique previously described 
by Smithers \&Terry (1965). The percent of reduction in worm number after challenge was calculated by the method of Tendler et al. (1986) as follows : $\mathrm{P}=\mathrm{C}-\mathrm{V} / \mathrm{C} \times 100$ where $\mathrm{P}=\%$ of protection, $\mathrm{C}=$ mean number of parasites recovered from infected animals, $V=$ mean number of parasites recovered from treated animals .

\section{Ova count:}

The number of ova / $\mathrm{g}$ tissue was counted by the method of Cheever \&Anderson (1971), where:

Number of ova $=$ Number of ova in $5 \mathrm{ml}$ $\mathrm{KOH} /$ weight of liver in grams recorded before digestion in $\mathrm{KOH}$

\section{Preparation of tissue homogenates and blood samples:}

Liver tissue was homogenized in bidistilled water in a ratio of $1: 10 \mathrm{~W} / \mathrm{V}$ for estimation of enzymes under investigation. Blood samples were collected from the reto -orbital venous pleux using capillary tubes. Serum samples were separated by centrifuging at $3000 \mathrm{rpm}$ for 10 minutes. Non hemolysed sera were used for estimation of the relevant biochemical parameters.

\section{Parameter assays:}

A-Serum analyses:

AST and ALT were estimated according to the method described by Bergmeyer et al. (1986), GGT was determined according to Schmidt \& Schmidt (1981), ALP was measured by using 4- nitrophenyl phosphate as substrate (Demetriou et al ., 1974), AP was determined according to Moss (1984), glucose was estimated according to Trinder, (1969), total lipids was determined using the method of Knight et al. (1972) total cholesterol and HDLcholesterol were determined enzymatically according to Stein, (1986), LDLcholesterol was calculated using the Friedewalds formula (Friedewald et al., 1972), triglycerides were estimated in the presence of glycerol kinase enzyme (Wahlefeld, 1974), total proteins was determined according to Cannon et al. (1974) using bovine serum albumin as reference standard. Finally, albumin was dete- rmined using bromcresol green (Doumas et al., 1971).

\section{B-Liver analyses:}

L- hydroxyproline was determined using Erlich' reagent (Jamall et al., 1981), xanthine oxidase was measured according to Bergmeyer , (1974), total ATPase $\left(\mathrm{Na}^{+}\right.$, $\mathrm{K}^{+}, \mathrm{Mg}^{+}$dependent) was assayed through measuring the inorganic phosphorus release (Bodansky \& Schwartz., 1963), PFK was determined using fructose -6- phosphate as substrate (Wu \&Racker, 1959) .

\section{Statistical analysis:}

Data were statistically computed and analyzed using One Way Analysis of Variance (ANOVA) followed by Least Signifcant Difference (LDS) post - hoc test (Snedecor \&Cochron, 1980).

\section{Results}

\section{1-Parasitological results:}

Table (1) shows that garlic and onion oils significantly reduced the worm burden and egg count $\left(\mathrm{G}_{2}\right.$ and $\left.\mathrm{G}_{3}\right)$ compared to the infected non - treated group $\left(\mathrm{G}_{1}\right)$.

\section{2-Biochemical results:}

\section{A-Serum parameters:}

Table (2) shows some serum liver function enzyme activities. The data show that a significant increase was obtained for liver function tests, namely ALT, AST, GGT, ALP, and AP in infected group $\left(\mathrm{G}_{4}\right)$ as compared to control uninfected group $\left(G_{1}\right)$. Table (3) illustrates a significant decrease in glucose concentration, total lipids total, cholesterol, HDL and LDL cholesterol, triglycerides, total proteins and albumin in $S$. mansoni infected animals $\left(\mathrm{G}_{4}\right)$ as compared to control one $\left(\mathrm{G}_{1}\right)$. Administration of garlic $\left(\mathrm{G}_{5}\right)$ or onion oils $\left(\mathrm{G}_{6}\right)$ after infection ameliorates most of these affected parameters. Healthy control mice administered with both drugs recorded non-significant change $\left(\mathrm{G}_{2}\right.$ and $\left.\mathrm{G}_{3}\right)$ as compared to control group $\left(\mathrm{G}_{1}\right)$.

\section{b- Liver parameters:}

Table (4) shows a significant increase in L-hydroxyproline concentration and $\mathrm{XO}$ 
enzymatic activity in infected group $\left(\mathrm{G}_{4}\right)$ as compared to control uninfected group $\left(\mathrm{G}_{1}\right)$, while significant decrease in the enzymatic activities of both total ATPases and PFK in S. mansoni infected group $\left(\mathrm{G}_{4}\right)$ as compared to control $\left(\mathrm{G}_{1}\right)$ was recorded.
Administration of garlic $\left(\mathrm{G}_{5}\right)$ or onion oils $\left(\mathrm{G}_{6}\right)$ after infection improved all measured parameters. Healthy control mice administered the two current drugs recorded non-significant change $\left(\mathrm{G}_{2}\right.$ and $\left.\mathrm{G}_{3}\right)$ as compared to control group $\left(\mathrm{G}_{1}\right)$.

Table (1): Worm burden and egg count in infected and treated groups.

\begin{tabular}{|c|c|c|c|c|c|c|}
\hline \multirow{2}{*}{ parameters } & Infected & $\begin{array}{c}\text { Infected+A. } \\
\text { sativum }\end{array}$ & $\begin{array}{c}\text { Infected } \\
\text { +A.cepa }\end{array}$ & \multicolumn{2}{|c|}{ Reduction percent } & \multicolumn{2}{c|}{$\begin{array}{c}\text { ANOVA } \\
\text { P }\end{array}$} \\
\cline { 2 - 6 } & $(1)$ & $(2)$ & $(3)$ & A.sativum & A.cepa & \\
\hline Worm & 34.33 & 11.00 & 8.25 & & & \\
burden & \pm 8.08 & \pm 3.65 & \pm 1.26 & 67.96 & 75.97 & 0.0001 \\
LSD & $(2,3)$ & $(1)$ & $(1)$ & & & 0.0001 \\
\hline Ova count & 5577.47 & 1427.62 & 995.75 & & \\
& \pm 864.73 & \pm 70.06 & \pm 90.53 & 74.40 & & \\
\hline
\end{tabular}

Data are means \pm S.D of 5 independent experiments.

Numbers between brackets indicate significant correlation.

Table (2): Effect of $A$. Sativum and $A$. cepa oils on serum liver function enzymes in control, infected and treated mice groups.

\begin{tabular}{|c|c|c|c|c|c|c|c|c|c|}
\hline \multirow{2}{*}{ Parameters } & \multirow{2}{*}{$\begin{array}{c}\text { Control } \\
\text { (1) }\end{array}$} & \multirow{2}{*}{$\begin{array}{l}\text { Control } \\
+ \text { A. } \\
\text { sativum } \\
\text { (2) }\end{array}$} & \multirow{2}{*}{$\begin{array}{c}\text { Control } \\
+ \text { A. cepa } \\
\text { (3) }\end{array}$} & \multirow{2}{*}{$\begin{array}{c}\text { Infected } \\
\text { (4) }\end{array}$} & \multirow{2}{*}{$\begin{array}{l}\text { Infected } \\
+ \text { A. } \\
\text { sativum } \\
\quad(5)\end{array}$} & \multirow{2}{*}{$\begin{array}{c}\text { Infected } \\
+ \text { A. cepa } \\
\text { (6) }\end{array}$} & \multicolumn{2}{|c|}{$\begin{array}{c}\text { Improvement } \\
\text { percent }\end{array}$} & \multirow{2}{*}{$\begin{array}{c}\text { ANOVA } \\
\mathrm{P}<\end{array}$} \\
\hline & & & & & & & $\begin{array}{c}\text { A. } \\
\text { Sativum }\end{array}$ & A. cepa & \\
\hline $\begin{array}{l}\text { AST (U/L) } \\
\text { LSD }\end{array}$ & $\begin{array}{c}34.43 \pm \\
2.29 \\
(2,4,5,6)\end{array}$ & $\begin{array}{c}28.41 \pm 1.67 \\
(1,4,5,6)\end{array}$ & $\begin{array}{c}32.18 \pm 1.46 \\
(4,5,6)\end{array}$ & $\begin{array}{c}125.91 \pm 3.93 \\
(1,2,3,5,6)\end{array}$ & $\begin{array}{c}56.63 \pm 3.13 \\
(1,2,3,4,6)\end{array}$ & $\begin{array}{c}68.34 \pm 3.22 \\
(1,2,3,4,5)\end{array}$ & 201.00 & 167.10 & 0.0001 \\
\hline $\begin{array}{l}\text { ALT(U/L) } \\
\text { LSD }\end{array}$ & $\begin{array}{c}34.91 \pm 4.50 \\
(4,5,6)\end{array}$ & $\begin{array}{c}36.41 \pm 0.76 \\
(4,5,6)\end{array}$ & $\begin{array}{c}34.88 \pm 1.74 \\
(4,5,6)\end{array}$ & $\begin{array}{c}86.35 \pm 3.37 \\
(1,2,3,5,6)\end{array}$ & $\begin{array}{c}49.18 \pm 6.72 \\
(1,2,3,4)\end{array}$ & $\begin{array}{c}53.60 \pm 3.72 \\
(1,2,3,4)\end{array}$ & 106.47 & 93.78 & 0.0001 \\
\hline $\begin{array}{l}\text { GGT(U/L) } \\
\text { LSD }\end{array}$ & $\begin{array}{c}14.54 \pm 1.99 \\
(4,5,6)\end{array}$ & $\begin{array}{c}16.07 \pm 0.59 \\
(4,5,6)\end{array}$ & $\begin{array}{c}15.81 \pm 1.89 \\
(4,5,6)\end{array}$ & $\begin{array}{c}47.45 \pm 3.22 \\
(1,2,3,5,6)\end{array}$ & $\begin{array}{c}24.40 \pm 1.78 \\
(1,2,3,4,6)\end{array}$ & $\begin{array}{c}30.94 \pm 2.17 \\
(1,2,3,4,5)\end{array}$ & 158.52 & 113.54 & 0.0001 \\
\hline $\begin{array}{l}\text { ALP (U/L) } \\
\text { LSD }\end{array}$ & $\begin{array}{c}78.63 \pm 2.30 \\
(4,5,6)\end{array}$ & $\begin{array}{c}73.97 \pm 2.74 \\
(4,5,6)\end{array}$ & $\begin{array}{c}75.10 \pm 1.27 \\
(4,5,6)\end{array}$ & $\begin{array}{c}174.77 \pm 3.35 \\
(1,2,3,5,6)\end{array}$ & $\begin{array}{c}96.71 \pm 1.83 \\
(1,2,3,4,6)\end{array}$ & $\begin{array}{c}109.86 \pm 4.99 \\
(1,2,3,4,5)\end{array}$ & 99.28 & 82.55 & 0.0001 \\
\hline $\begin{array}{l}\text { AP (U/L) } \\
\text { LSD }\end{array}$ & $\begin{array}{c}9.65 \pm 1.36 \\
(4,5,6)\end{array}$ & $\begin{array}{c}10.67 \pm 1.23 \\
(4,6)\end{array}$ & $\begin{array}{c}10.52 \pm 2.01 \\
(4,5,6)\end{array}$ & $\begin{array}{c}30.98 \pm 1.99 \\
(1,2,3,5,6)\end{array}$ & $\begin{array}{c}16.207 \pm 6.54 \\
(1,3,4)\end{array}$ & $\begin{array}{c}21.48 \pm 2.25 \\
(1,2,3,4)\end{array}$ & 153.09 & 98.44 & 0.0001 \\
\hline
\end{tabular}

Data are means \pm S.D of 5 independent experiments

Numbers between brackets indicate significant correlation. 
Nadia S. Metwally 
Potency of Allium sativum and Allium cepa...... 


\section{Nadia S. Metwally}

\section{Discussion}

Previous studies have shown that the interaction between schistosoma parasites and human host is extremely complex. Many parasitologists have focussed their studies on the epidemiology of schistosomiasis or the physiology of the parasites, neglecting to some extent the metabolic relationship between parasites and the host in consequence to infection or drug treatment (Soliman et al., 2001). This study was performed to evaluate the antischistosomal efficacy of garlic ( $A$. sativum) and onion (A. cepa) oils for controlling schistosomiasis and the associated metabolic disturbances in experimentally infected mice.

The antischistosomal effect of either garlic or onion may be attributed to their effects on the host immune response. Previous studies showed that garlic enhances the protective immunity against parasitic infection by various mechanisms: 1- It increases the entrance of the parasite into macrophage because it contains mannose - binding lectins (Dam et al .,1998) which facilitates the attachment of the parasite to the receptor on the surface of the macrophage which then engulf the parasite (Ghazanfari et al., 2006). 2- By enhancing the production of nitric oxide (NO) from both blood platelets and macrophages as an important effector in the parasite destruction (Das et al., 1996). 3- It contains an immunomodulator fraction, which affects the course of infection and shifts the cytokine pattern from $\mathrm{T}$ helper 2-lymphocyte-mediated immune responses, responsible for granuloma formation, to $\mathrm{T}$ helper 1-lymphocyte-mediated immune responses, responsible for immune resistance (Ghazanfari, 2000).

However, the antischistosomal efficacy of onion may be suggested that it acts as immunomodulator which is important in limiting the immunopathological reaction against schistosome eggs trapped within the liver (Chisty et al., 1996).

Our data demonstrated that treatment with either garlic or onion oils were effective in reducing worm burden and ova count indicating their schistosomicidal activities. The reduction in egg count in our study may be attributed to the reduction in worm burden and / or these drugs may affect the ability of both male and female worms to couple and consequently affect egg output by female adult worms. These results are in harmony with other investigators who used plant extracts including garlic and onion for the treatment of parasitic infections (Abu-El-Ezz., 2005; Ellakkany et al., 2004., Ghazanfari et al., 2006; Hamed \& Hetta, 2005; Mahmoud et al., 2002; Mohamed et al., 2005).

The main cause of mortality and morbidity in human schistosomiasis is hepatic fibrosis which is essentially dependent on granulomas (Warren,1978). Granulomatous inflammation in schistosomiasis is a cell mediated hypersensitivity to parasite egg antigens that are lodged in hepatic tissue (Warren et al.,1967). As granulomas evolve, collagen fibers deposit around the eggs, a process that lead to fibrosis (Lenzi et al., 1999). In the present work, the amount of collagen deposition was documented by measuring of hydroxyproline concentration in liver of infected mice. Our data showed a significant increase in hydroxyproline level in liver tissues of S. mansoni infected mice compared to control uninfected mice. These results are in accordance with some authors suggesting that $S$. mansoni egg granulomas contain a factor (s) which may be responsible for the elevation of free-Lhydroxyproline content in the fibrotic liver (Potter et al., 2003; Pyrrho et al., 2002; Adewusi et al., 1996).

An early event following infection with $S$. mansoni is the production of reactive oxygen species (ROS) which induces hepatic oxidative stress leading to destruction of hepatocytes (Abdallahi et al., 1999). These ROS may initiate lipid peroxidation, leading to membrane damage and the generation of further toxic products (Clark et al., 1985). Oxidases such as xanthine oxidase have been postulated as important 
cellular sources of ROS that can produce oxidative stress, which inflicts tissue injury. Xanthine oxidase (XO) activity is reported to increase in several disorders concomitant with oxygen radical production (Ghezzi et al., 1985). The main physiologic function of the enzyme is in purine catabolism, where it catayzes the oxidation of hypoxanthine to xanthine and the latter to uric acid (Fridovich, 1970). The enzyme exists in two interconvertible forms, a dehydrogenase and an oxidase form, both forms generate ROS, but under physiological conditions, XO exists predominantly in dehydrogenase form which is inhibited by $\mathrm{NAD}^{+}$. Since the cells normally contain large amounts of $\mathrm{NAD}^{+}$, dehydrogenase has no physiological significance (Corte \& Stripe, 1972). The conversion of the dehydrogenase form to oxidase can occur by proteolysis or by reversible oxidation of sulfhydryl groups (Batelli et al., 1973). While oxidizing its substrate, $\mathrm{XO}$ uses oxygen as an electron acceptor and generates superoxide anion radical and hydrogen peroxide as by - product (Winterbourn \& Sutton, 1986) . Moreover, XO - derived $\mathrm{O}_{2}{ }^{\circ}$ can impair nitric oxide ( $\mathrm{NO}$ ) signaling and concomitantly yield secondary oxidizing species, such as peroxynitrite (ONOO') that can further propagate tissue injury (Villa et al., 1994). In this work, XO is shown to increase in liver of infected mice compared to control (Table 4). These data are in agreement with Stripe et al. (2002) who reported that the percentage of oxidase activity seems to be correlated with tissue damage and consequent liver impairment.

ROS production under the stress of schistosomiasis not only alters the functional integrity of cell membranes, but also affects the activities of various membranes - bound enzymes including total ATPase $\left(\mathrm{Mg}^{+}\right.$and $\mathrm{Na}^{+} \mathrm{K}^{+}$ATPase). According to Shaheen \& Ebeid (1992), the present study revealed a significant decrease in hepatic ATPase activity in S. mansoni infected group compared to control uninfected group. ATPases are lipid dependent membrane-bound enzymes involved in active transport process and have been implicated in the pathogenesis of liver -cell injury, further toxic insult of liver can promote a variety of chemical reactions including depletion of reduced glutathione (GSH) which affect membrane bound ATPases as they require $\mathrm{SH}$ group to maintain their structure and function (Kaplowitz, 2002) . In addition, Kako et al. (1988) reported that disruption of this enzyme may have occurred by oxidation of its vital sulfhydryl "SH" groups, present in the active sites leading to its inhibition. Decreased ATP production subsequent to inhibition of these enzymes could have profound effects on numerous cellular functions, including $\mathrm{Ca}^{2+}$ homeostasis and maintenance of membrane integrity. The author also reported that the membrane-bound ATPase is concerned with the maintenance of a low intracellular concentration of $\mathrm{Na}^{+}$, so a decrease in activity of $\mathrm{Na}^{+}-\mathrm{K}^{+}$-ATPase can lead to a decrease in sodium efflux and thereby increase cell membrane permea-bility (Kako et al., 1988).

Impairment of cell membrane permiability leads to release of enzymes to circulation. In line with some authors, the present study revealed a significant increase in serum AST, ALT, GGT, ALP and AP activities in all infected mice in compared to control indicating cell damage induced by schistosome egg deposition (Giboda et al., 1994; El-Sokkary et al.,2002; Mahmoud et al., 2002).

The most striking effect of $S$. mansoni infection on host intermediary metabolism is reflected by dramatic reductions in tissue carbohydrate level. Depletion of blood glucose, for example, was reported by Shaheen et al. (1989) and Soliman et al. (2001) who found a significant depletion of glycogen in livers of infected mice. The significant decrease in serum glucose level observed in the present study is consistent with the elevated respiration observed in many host-trematode associations described earlier, as well as, many in vivo and in vitro studies that have firmly established that glucose is rapidly absorbed and forms the principal energy nutrient for trematode parasites during their development. This rapid utilization of glucose appears sufficient to also deplete carbohydrate reserves from tissues of infected mice and to increase the uptake of exogenous glucose 
from the diet (Coles, 1973). The decrease in liver phosphofructokinase (PFK) enzyme activity presented in our study following infection, added further support to previous findings that might be explained by the alterations in carbohydrate metabolism. In contrast, Ahmed \& Gad (1995) found a remarkable increase in the enzyme activity from the fourth week of infection and concluded that glycolysis is largely stimulated in the livers of infected mice on the expense of other metabolic pathways of glucose utilization.

Little is known about potential role of lipids in animals infected with $S$. mansoni parasite. Our results showed a significant decrease in all tested parameters in serum including, total lipids, total cholesterol, triglycerides, HDL and LDL of infected animals. These findings are in accordance with El- Marzouki \&Amin (1997) and Doenhoff et al. (2002) who reported that these changes might be attributed to several metabolites released by schistosomes which affect the host hepatic tissue resulting in decreased synthesis of these parameters and their release into the circulation. In contrast, El-Sokkary et al. (2002) reported an increase in serum cholesterol level in S. mansoni infected mice. This decrease in lipid profiles in infected mice may be explained on the basis that adult schistosomes apparently have limited capacity to synthesize and metabolize lipids, but are known to require specific lipids for development and maturation. Consequently they may rapidly absorb their host lipid reserves i.e. mobilization and oxidation of lipid reserves increases during infection (Newport \&Weller., 1982).

Reduction in total protein level in serum and tissues of animals during trematode infection have been reported on numerous occasions. The present work, showed a significant decrease in serum total proteins and serum albumin of infected mice compared to control uninfected mice. These data are in consistent with Mahmoud et al.(2002). This obtained decrease in total proteins may be attributed to that $S$. mansoni parasite has the usual nutritional requirement for essential amino acids, suggesting that amino acids may provide an alternative energy source to carbohydrate for host metabolism or contribute to glucose synthesis and carbohydrate repletion through gluconeogenesis in infected animals. This, in turn, indicates a high level of deamination or transamination. In addition, such decrease may also occur as a result of tissue damage and the action of hydrolytic enzymes released by developing parasites or host lysosomes.

The present results recorded amelioration of liver function enzymes and variabley improvement of other parameters after treatment of infected mice with either garlic or onion oils. This amelioration may be due to the presence of flavonoids and organosulfur compounds which are considered responsible for their beneficial effects (Sengupta et al., 2004, O'Reilly, 2001). Flavonoids include the flavonols, quercetin, kaempferol and myricetin found in garlic and onion, are polyphenolic compounds found in many foods of plant origin (Wiseman, 1999; Hollman, 1997). They have a protective effect against coronary heart disease; this effect was thought to be a result of their antioxidant action. Quercetin, which is present abundantlly in onion, displays potent antioxidant properties in vitro, mostly against oxidative damage to membrane lipids and lipoprotein particles (O'Reilly et al ., 1997) .

The most abundant organosulfur compound in garlic is $\mathrm{S}$ - allylcystein (SAC) which has antioxidant properties and could be one of the active compounds responsible for the protective effect of garlic in several experimental models associated with oxidative stress (Maldonado et al., 2003; Kim et al., 2001). $\mathrm{SAC}$ has antioxidant properties both in vivo and in vitro. In vivo, it reduces edema formation in the ischemic rat brain by inhibiting lipid peroxidation (Numagami \& Ohnishi, 2001), and it reduces the histological damage in heart and liver of mice treated with doxorubicin, a carcenogenic drug (Mostafa et al ., 2000) . In vitro, $\mathrm{SAC}$ is able to scavange $\mathrm{O}_{2}^{-}, \mathrm{H}_{2} \mathrm{O}_{2}$ and HO (Ide \& Lau 2001; Kim et al., 2001). SAC also prevents $\mathrm{H}_{2} \mathrm{O}_{2}$-induced endothelial cell injury, lipid peroxidation and low density lipoprotein oxidation (Ide \& Lau, 
2001). Finally, SAC differentially regulates nitric oxide (NO) production by inhibiting inducible nitric oxide synthase expression in macrophages while increasing $\mathrm{NO}$ in endothelial cells that may contribute to its anti - inflammatory effect( Kim et al., 2001).

In conclusion, the oxidative processes that occur upon infection with $S$. mansoni seem to go uncontrolled; such events may be, at least, in part, responsible for the pathology associated with schistosomiasis. At the same time treatment with both garlic and onion oils may be beneficial for their immunomodulating and antioxidative actions. In addition, the current drugs have no side effects on normal healthy animals and succeeded to reduce the hazardous effects of $S$. mansoni through improvement of liver enzymes, reduction of worm burden and ova count. Our recommendation is to increase the treatment time of both drugs for complete eradication of worm and ova and also new researches should be undertaken to isolate the active ingredients of both drugs in order to become feasible to test.

\section{Aknoledgement:}

We are grateful to Dr. Abdel Hamid Zaki Abdel Hamid for his help.

\section{References}

1. Abdallahi OMS, Hanna S, deReggi M. and Gharib B. (1999): Visulization of oxygen radical production in mouse liver in response to infection with Schistosoma mansoni. Liver 19:495-500.

2. Abu-El-Ezz NM. (2005): Effect of Nigella sativa and Allium cepa oils on Trichinella spiralis in experimentally infected mice. J. Egypt. Soc. Parasitol. 35(2), 511-523.

3. Adewusi OL, Nix NA, Lu X, Colley DG. and Secor WE. (1996): Schistosoma mansoni: Relationship of tumor necrosis factor-7 to morbidity and collagen deposition in chronic experimental infection. Experimental Parasitology. 84(2): 115-123.

4. Ahmed SA. and Gad MZ. (1995): Effect of schistosomal infection and its treatment on some key enzymes of glucose metabolism in mice livers. Arzneimittelfor schung. 45(12): 1424-1328.

5. Batelli MG, Lorenzoni E. and Stirpe F. (1973): Milk oxidase type D (dehydro- genase) and type $\mathrm{O}$ (oxidase). Purification, interconversion and some properties. Biochem. J. 131: 191-198.

6. Belman S. (1983): Onion and garlic oils inhibit tumor formation. Carcinogenesis 4 : 1063-1065.

7. Bergemeyer HU. (1974): In "Methods of Enzymatic Analysis" HU Bergmeyer (Ed.) Academic Press, London, pp. 644-649.

8. Bergmeyer HV, Herder M. and Rej R. (1986): Approved recommendation (1985) on IFCC methods for the measurement of catalytical concentration of enzymes. Part 2.IFCC method for aspartate aminotransferase. J. Clin. Chem. Clin. Biochem. 24: 497.

9. Bodansky O. and Schwartz MK. (1963): comparative effects of L-histidine on the activities of 5'- nucleotidase and alkaline phosphatase. J. Biol. Chem. 238: 34203427.

10. Cannon DC. (1974): In " Clinical Chemistry Principles and Techniques ", $2^{\text {nd }}$ Ed. RJ Henry et al., Eds. Harper \& Row, Hagerstown, MD, pp. 411-421.

11. Casini A, Ceni E, Salzano R, Biondi P, Parola M. and Galli A. (1997): Neutrophil-derived superoxide anion induces lipid peroxidation and stimulates collagen synthesis in human hepatic stellate cells: role of nitric oxide. Hepatology 25: 361-367.

12. Caulfield JP, Lenzi HL, Elsas P. and Dessein AJ. (1985): Ultrastructure of the attack oesinophils stimulated by blood mononuclear cell products on schistosomula of Schistosoma mansoni. Am. J. Pathol. 120: 380-390.

13. Cheever AW. and Anderson LA. (1971): Rate of destruction of Schistosoma mansoni eggs in tissues of mice. Am. J. Trop. Med. Hyg. 20: 62-68.

14. Chisty MM, Quddus R, Islam B. and Khan BR. (1996): Effect of onion extract on immune response in rabbits. Bangladesh Med. Res. Counc. Bull. 22(2): 81-85

15. Clark IA, Cowden WB. and Hunt NH. (1985): Free radical-induced pathology. Med. Res. Rev. 5(3): 297-335.

16. Coles GC. (1973): The metabolism of schistosomes: a review, Int. J. Biochem. 4: 319.

17. Corte EO. and Stirpe F. (1972): The regulation of rat liver xanthine oxidase. Involvement of thiol groups in the conversion of the enzyme activity from dehydrogenase (type D) into oxidase (type O) and purification of the enzyme. Biochem. J. 126:739-745. 
18. Dam TK, Bachhawat K, Rani PG. and Surolia A. (1998): Garlic (Allium sativum) lectins bind to high mannose oligosaccharide chains. J. Biol. Chem. 273: 55285535.

19. Das I, Hirani J. and Soorama S. (1996): Arginine is not responsible for the activation of nitric oxide synthase by garlic. J. Ethnopharmacol. 53: 5-9.

20. Demetriou IA, Drewes DA. and Cln JB. (1974): Enzymes In " Clinical ChemistryPrinciples and Technics" $2^{\text {nd }}$ ed. RJ Henry; DC Cannon; JW Winlelman. Eds. Harper\& Row Hagerstown MD pp. 927.

21. Doenhoff MJ, Stanley RG, Griffiths K. and Jackson CL. (2002): An antiatherogenic effect of Schistosoma mansoni infection in mice associated with a parasiteinduced lowering of blood total cholesterol. Parasitol. 125(5): 415-421.

22. Doumas BT, Watson WR. and Biggs HG. (1971): Albumin standard and measurement of serum albumin with bromocresol green. Clinica. Chimica Acta. 31: 87-96.

23. Duraka A, Ozturk HS, Olcay E. and Guven C. (2002): Effects of garlic extract supplementation on blood lipid and antioxidant parameters and atherosclerotic plaque formation process in cholesterol-fed rabbits. Journal of Herbal Pharmacotherapy 2: 19-32.

24. El-Lakkany NM, Sief el-Din SH, Badawy AA. and Ebeid FA. (2004): Effect of artmether alone and in combination with grape fruit on hepatic drug-metabolising enzymes and biochemical aspects in experimental Schistosoma mansoni. Int. J. Parasitol. 34: 1405-1412.

25. El-Marzouki ZM. and Amin AM. (1997): Changes in serum lipids of mice experimentally infected with Schistosoma mansoni. J. Egypt. Soc. Parasitol. 27(2): 419-429.

26. El-Sokkary GH, Omar HM, AbdelFattah M, Hassanein M, Cuzzocrea S. and Retter R. (2002): Melatonin reduces oxidative damage and increases survival of mice infected with Schistosoma mansoni. Free Radical Biology and Medicine. 32(4): 319-332.

27. Flisser A. and Mclaren DJ. (1989): Effect of praziquantel treatment on lung stage larvae of Schistosoma mansoni in vivo. Parasitology. 98: 203-211.

28. Fridovich I. (1970): Quantitative aspects of the production of superoxide anion radical by milk xanthine oxidase. J. Biol. Chem. 245: 4053-4057.
29. Friedewald WT, Levy RI. and Fredrickson DS. (1972): Estimation of the concentration of low-density lipoprotein cholesterol in plasma, without use of the preparative ultracentrifuge. Clin. Chem. 18: 499-502.

30. Ghazanfari T, Hassan ZH. and Khamespour A. (2006): Enhancement of peritoneal macrophage phagocytic activity against Leishmania major by garlic (Allium sativum) treatment. J. Ethnopharmacol. 103: 333-337.

31. Ghazanfari T, Hassan ZM. and Ebrahimi M. (2002): Immunomodulatory activity of a protein isolated from garlic extract on delayed type hypersensitivity. International Immunopharmacology 2:1541-1549.

32. Ghazanfari T, Hassan ZM, Ebtekar M, Ahamiani A, Naderi G. and Azar A. (2000): Garlic induces a shift in cytokine pattern in Leishmania major infected $\mathrm{Balb} / \mathrm{c}$ mice. Scandinavian Journal of Immunology. 52:491-496.

33. Ghezzi P, Bianchi M, Gianera L, Landolfo S. and Salmona M. (1985): Role of reactive oxygen intermediates in the interferon-mediated depression of hepatic drug metabolism and protective effect of $\mathrm{N}$ acetylcysteine in mice. Cancer Res. 45: 3444-3447

34. Giboda M, Smith JM. and Prichard RK. (1994): Reduction in tissue egg load and maintenance of resistance to challenge in mice infected with $S$. mansoni following combined treatment with praziquantel and an antifibrotic agent. Annals of tropical Medicine and Parasitology. 88: 385-395.

35. Griffiths G, Trueman L, Crowther T, Thomas B. and Smith B. (2002): Onions: A global benefit to health. Phytother. Res. 16: 603-615.

36. Hamed MA. and Hetta MH. (2005): Efficacy of Citrus reticulata and Mirazid in treatment of Schistosoma mansoni. Mem. Inst. Oswaldo. Cruz. 100(7): 771-778.

37. Hassan ZM, Yaraee R, Zare N, Ghazanfari T, Sarf Nejad AHS. and Nozari B. (2003): Immunomodulatory effect of R10 fraction of garlic extract on NK activity. Journal of International Immunopharmacology 3: 1483-1489.

38. Helen A, Krishnakumar K, Vijay-ammal PL. and Augusti KT. (2000): Antioxidant effect of onion oil (Allium cepa. L) on damages induced by nicotine in rats as compared to alphatocopherol. Toxical. Letter. 116: 61-68. 
39. Hollman PCH. (1997): Bioavailability of flavonoids. Eur. J. Clin. Nutr. 51: 66-69.

40. Ide N. and Lau BH. (2001): Garlic compounds minimize intracellular oxidative stress and inhibit nuclear factor kB activation. J.Nutr. 131: 1020-1026.

41. Jamall IS, Finelli VN. and QueHee SS. (1981): A simple method to determine nanogram levels of 4-hydroxyproline in biological tissues. Anal. Biochem. 112: 7075.

42. Kabatereine NB, Kemijumbi J, Ouma JH, Sturrock RF, Butterworth AE, Madsen H, Ornbierg N, Dunne DW. and Vennervald BJ. (2003): Efficacy and side effects of praziquantel treatment in a highly endemic Schistosoma mansoni focus at lake Albert, Uganda. Trans.Soc. Trop. Med. Hyg. 97: 599-603.

43. Kako K, Kato M, Matsuoka T. and Mustapha A. (1988): Depression of membrane bound $\mathrm{Na}^{+} \mathrm{K}^{+}$ATAase activity induced by free radicals and by Ischaemia of kidney. Am. J. Physiol. 254: 330-334.

44. Kaplowitz N. (2002): Biochemical and cellular mechanisms of toxic liver injury. Seminar in Liver Diposition 22: 137-144.

45. Karasaki Y, Tsukamoto S, Mizusaki K, Sugiura T. and Gotoh S. (2001): A garlic lectin exerted an antitumor activity and induced apoptosis in human tumor cells. Food Research International 34: 7-13.

46. Kim KM, Chun SB, Koo MS, Choi WJ, Kim TW, Kwon YG, Chung HT, Billiar TR. and Kim YM. (2001): Differential regulation of NO availability from macrophages and endothelial cells by the garlic component of S-allylcysteine. Free Radic. Biol. Med. 30:747-756.

47. Knight JA, Anderson S. and Rawie JM.(1972): Chemical basics of the sulfophosphovanilin reaction for estimating total serum lipid. Clin. Chem.18:199-202

48. Kumar VG, Surendranathan KP, Umesh KG,Gayathri Devi DR. and Belwadi MR. (2003): Effect of onion (Allium cepa Linn.) and garlic (Allium sativum Linn) on plasma triglyceride content in Japanese quail (Coturnix conturnix Japonicum). Indian Journal of Experimental Biology 41: 88-90.

49. Kumari K, Hathew BC. and Augusti KT. (1995): Antidiabetic and hypolipidemic effect of S-methyl-cysteine sulfoxide isolated from Allium cepa L. Ind. J. Biochem. Biophys. 32: 49-54.

50. Lenzi HL, Kimmel E, Schechtman H, Pelago-Machado M, Vale BS, Panasco MS. And Lenzi JA. (1999): Collagen arrangement in hepatic granuloma in mice infected with Schistosoma mansoni: dependence on fiber radiation centers. Braz. J. Med. Biol. Res. 32: 639-643.

51. Mahmoud MR, El-Abhar HS. and Saleh S. (2002): The effect of Nigella sativa oil against the liver damage induced by Schistosoma mansoni infection in mice. J. Ethnopharmacol. 79: 1-11.

52. Maldonado PD, Barrera D, Rivero I, Mata R, Medina-Campos ON, Hernandez- Pando R. and PedrazaChaverri J. (2003): antioxidant Sallylcysteine prevents gentamicin-induced oxidative stress and renal damage. Free Radic. Biol. Med. 35(3): 317-324.

53. Mantawy MM. and Mahmoud AH. (2002): Effect of Allium cepa and Allium sativum feeding on glucose, glycogen, protein bands profile and phenol oxidase activity in Biomophalaria alexandrina. J. Egypt. Soc. Parasitol. 32(1): 271-283.

54. Mohamed AM, Metwally NM. and Mahmoud SS. (2005): Sativa seeds against Schistosoma mansoni different stages. Mem.Inst. Oswaldo. Cruz. 100(2): 205-211.

55. Moss DW. (1984): In " Methods of Enzymatic Analysis " Ed. HU Bergmeyer, Verlag-Chemie, $3^{\text {rd }}$ edition, Vol. 4, pp 92106.

56. Mostafa MG, Mima T. and Ohnishi ST. (2000): S-allylcysteine ameliorates doxorubicin toxicity in the heart and liver in mice. Planta. Med. 66: 148-151.

57. Newport GR. and Weller TH. (1982): Deposition and maturation of eggs of Schistosoma mansoni in vitro: importance of fatty acids in serum-free media. Am. J. Trop. Hyg. 3: 349.

58. Numagami Y. and Ohnishi ST. (2001): Sallylcysteine inhibits free radical production, lipid peroxidation and neuronal damage in rat brain ischemia. J. Nutr. 131: 11005-11055.

59. O'Reilly J, Pollard L, Leake D, Sanders TAB. and Wiseman H. (1997): Quercetin is a potent inhibitor of oxidative damage of human LDL isolated from fresh and frozen plasma. Proc. Nutr. Soc. 56: 287A.

60. O'Reilly JD, Mallet AI, McAnlis GT, Young IS, Halliwell B, Sanders TAB. and Wisman H. (2001): Consumption of flavonoids in onions and black tea: Lack of effect on $\mathrm{F}_{2^{-}}$isoprostanes and autoantibodies to oxidized LDL in heathy humans. Am. J. Clin. Nutr. 73(6): 1040-1044.

61. Oliver L. and Stirewalt MA. (1952): An efficient method for the exposure of mice to 
cercariae of Schistosoma mansoni. J. Parasitol. 39: 19-23.

62. Potter JJ, Tankesley LR. And Mezey E. (2003): Influence of leptin in the development of hepatic fibrosis produced in mice by Schistosoma mansoni infection and by chronic carbon tetrachloride administration. J. Hepatology. 38: 281-288.

63. Pyrrho AS, Ramos JA, Neto RM, de Silva CS, Lenzi HL, Takiya CM. and Gattass CR. (2002): Dexamethasone, a drug for Attenuation of Schistosoma mansoni Infection Morbidity. Antimicrobial Agents and Chemotherapy. 46(11): 34903498.

64. Saleheen D, Ali SA. and Yasinzai MM. (2004): Antileishmanial activity of aqueous onion extract in vitro. Fitoterpia 75: 9-13.

65. Schmidt E. and Schmidt FW. (1981): Kline Enzyme Fiebel Schriftenreihe. Diagnostic Boehringer Mannheim, $3^{\text {rd }}$ ed.

66. Sengupta A, Ghosh S. and Bhattacharjee S. (2004): Allium vegetables in cancer prevention: an overview. Asian Pac. J. Cancer. Prev. 5(3): 229-230.

67. Shaheen AA. and Ebeid A. (1992): Effect of praziquantel treatment on brain and kidney ATPase activities in healthy and Schistosoma mansoni infected mice. Arzneimittelforschung. 42(12): 1504-1506.

68. Shaheen AA, Ebeid FA. and Fahim AT. (1989): Effect of praziquantel on some aspects of carbohydrate metabolism in mice infected with Schistosoma mansoni. Pharmacological Research 21(3): 263-270.

69. Silva LM, Menezes RM, DeOliveira SA. and Andrade ZA. (2003): Chemot-herapeutic effects on larval stages of Schistosoma mansoni during infection and reinfection of mice. Rev. Soc. Bras. Med. Trop. 36: 335341.

70. Smithers SR. and Terry RJ. (1965): The infection of laboratory hosts with cercariae of Schistosoma mansoni and recovery of worms. Parasitology 55: 695-700.

71. Snedecor GW. and Cochron WG. (1980): Statistical Methods $7^{\text {th }}$ Ed, Iowa State Univ. Press, Iowa, USA.

72. Soliman K, El-Ansary A. and Mohamed AM. (2001): Effect of carnosine administration on metabolic parameters in bilharzias-infected hamsters. Comp. Biochem. Physiol. 129(B): 157-164.

73. Stein EA. (1986): In " Textbook of Clinical Chemistry " NW Tiez \& WB saunder eds.,
Philadelphia pp. 879-886, 1818-1829.

74. Stirpe F, Ravaioli M. Battelli MG. Musiani S. and Grazi GL. (2002): Xanthine oxidoreductase activity in human liver disease. Am. J. Gastroenterol. 97(8): 2079-2085.

75. Tendler M, Pinto RM, Oliveira LA, Gebara G. and Katz N. (1986): Schistosoma mansoni vaccination with adult worm antigens. Int. J. Parasitol. 16: 347-352.

76. Trinder P. (1969): Determination of glucose in blood using glucose oxidase with an alternative oxygen acceptor. Ann. Clin. Biochem. 6: 24.

77. Villa LM, Salas E, Darley-Usmar VM, Radomski MW. and Moncada S. (1994): Peroxynitrite induces both vasodilatation and impaired vascular relaxation in the isolated perfused rat heart. Proc. Natl. Acad. Sci. USA. 91: 12383-7.

78. Wahlefeld AW. (1974): In " Methods of Enzymatic Analysis ". Vol.5, HU Bergmeyer Ed. Academic Press, New York, pp. 1831-1835.

79. Warren KS. (1978): The pathology, pathobiology and pathogenesis of schistosomiasis. Nature 273: 609-612.

80. Warren KS, Domingo EO. and Cowan RB. (1967): Granuloma formation around schistosome eggs as manifestation of delayed hypersensitivity. Am. J. Pathol. 51: 735-756.

81. Winterbourn CC. and Sutton HC. (1986): Iron and xanthine oxidase catalyze formation of an oxidant species distinguishable from $\mathrm{OH}$ : comparison with the Haber-Weiss reaction. Arch. Biochem. Biophys. 244: 27-34.

82. Wiseman H. (1999): The bioavailability of non-nutrient plant factors: dietary flvonoids and phyto-oestrogens. Proc. Nutr. Soc. 58: 139-146.

83. Wu R. and Racker E. (1959): Regulatory mechanisms in carbohydrate metabolism III limiting factors in glycolysis of ascites tumor cells. J. Biol. Chem. 234: 1029-1035.

84. Yoshida H, Iwata N. and Katsuzaki H. (1998): Antimicrobial activity of a compound isolated from an oil-macerated garlic extract. Biosciences Biotecnology Biochemistry 62: 1014-1017.

85. Yu TH, Wu CM. and Liou YC. (1989): Volatile compounds from garlic. J. Agric. Food Chem. 37: 725-730. 


\section{القوة الفعالة لزيوت الأليم ساتيفا والأليم سيبا ضد الاصابة بطقيل

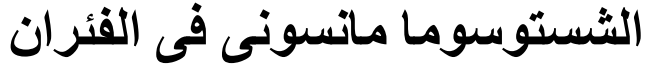

\section{نادية محمد سعيد متولى المئ

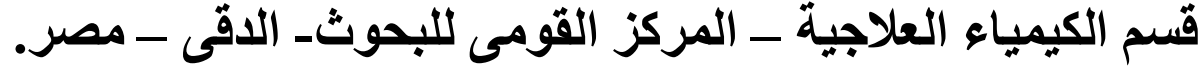

المقدمة : من المقرر على مستوى العالم ان الثوم ( الأليم ساتيفا ) و البصل ( الأليم سيبا

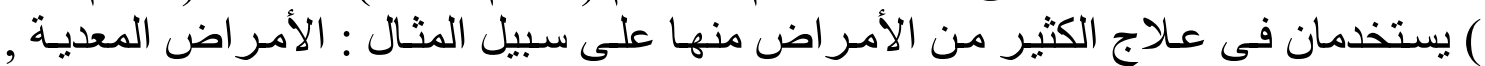

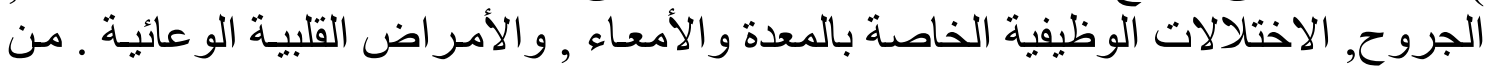

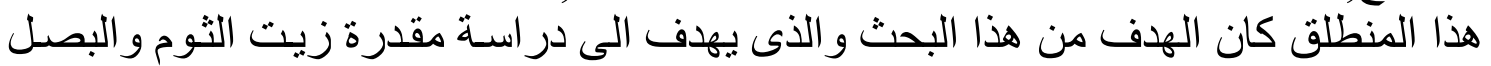

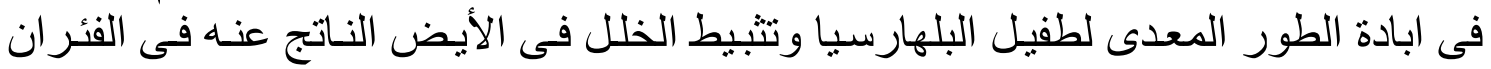

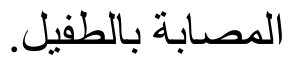

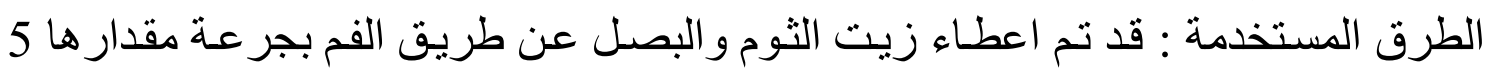

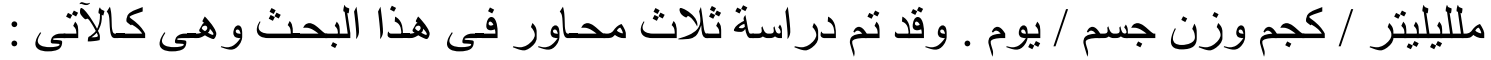

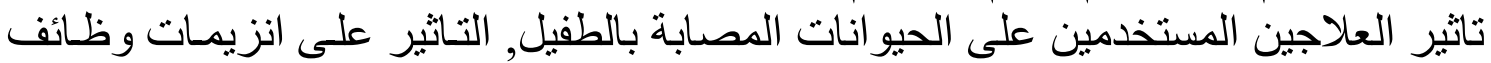

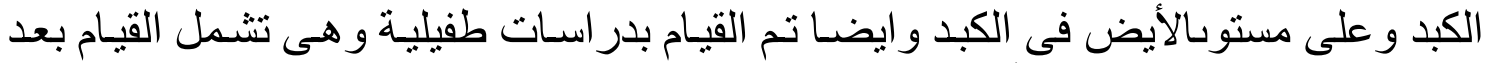

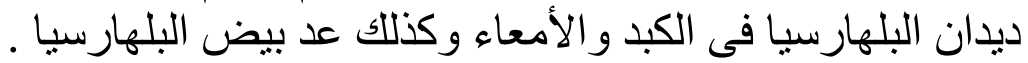

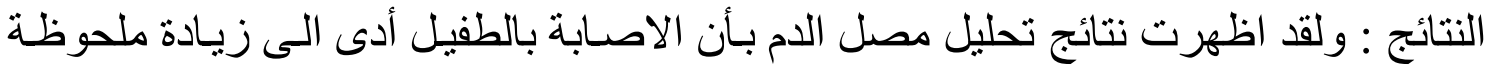

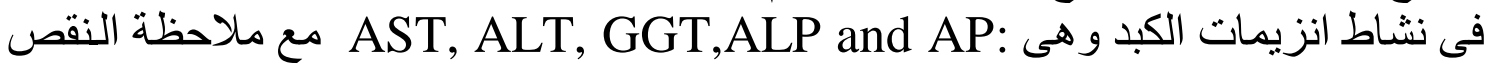

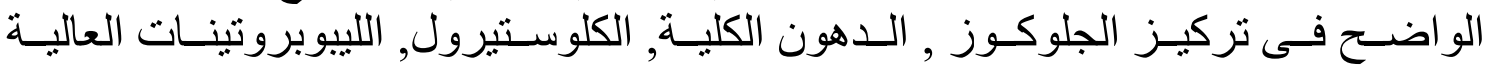

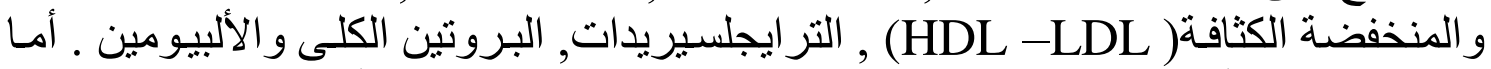

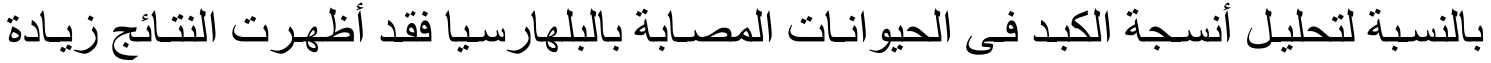

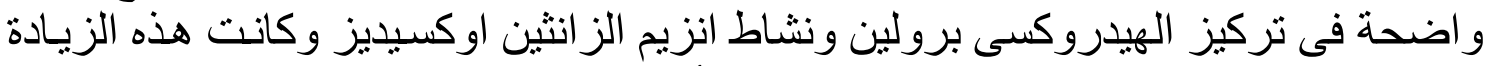

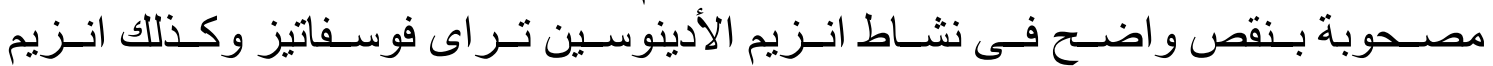

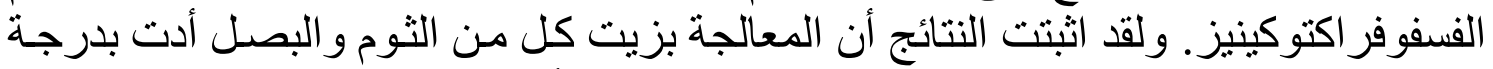

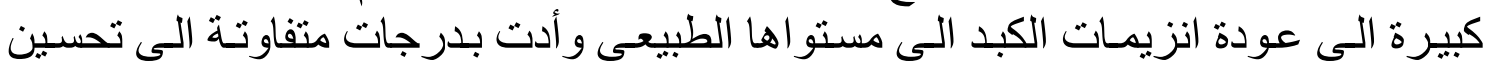

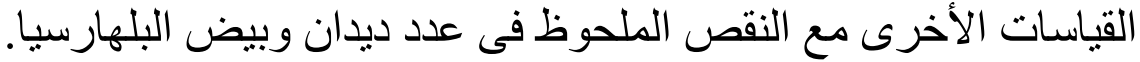

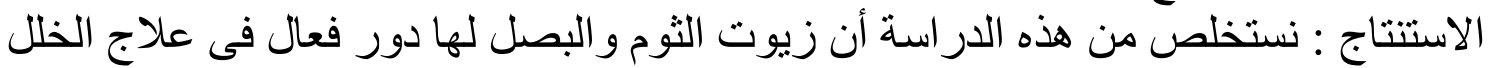

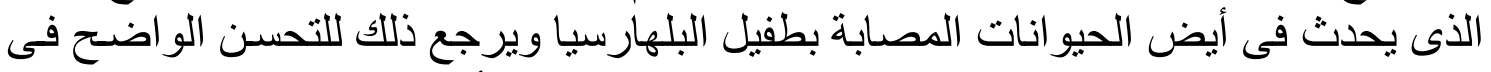
الجهاز المناعى للحيو انات و ايضا لاحتو ائهم على مضادات الأكسدة. 